\title{
Control as an educational tool and its impact on the outdoor educational process.
}

\author{
Ina Stan \\ Buckinghamshire New University
}

\begin{abstract}
Mainstream education studies have shown that teachers have a strong desire to control their work situation and maintain classroom autonomy. Issues of control and power are also prevalent in outdoor education, where the facilitator is put in a position of power, controlling the participants' learning experience. What follows is an examination of how order and instructions are used, on occasion, by facilitators in an outdoor setting to take control over the activity and achieve their own disciplinary goals. This paper was based on a PhD study conducted at a residential outdoor centre, involving primary school children, teachers and the centre staff. An ethnographic approach was adopted, using participant observation and semi-structured interviews to collect varied data. The findings revealed that the controlling approaches adopted by some facilitators interfered with the pupils' outdoor learning experience. This level of control appeared to have a great impact on the educational process to the extent that the desired learning outcomes were not attained. This has serious implications on the impact that teachers' and outdoor facilitators' approaches have on the pupils' outdoor learning experience, and more awareness is needed with regard to this impact.
\end{abstract}

This paper examines how facilitators and teachers alike use power in an outdoor education setting to control the experience of the children taking part in outdoor activities. Particularly, it conducts an in-depth analysis of the impact that control can have on the outdoor educational process. It also explores an alternative way to using control as an educational tool, and its effects on the children's outdoor learning experience. Teacher and facilitator are used here interchangeably in this paper.

First, I will define the concepts of power and control as used in this paper, and how they are applied to an educational setting. I will also explain the methodological approach used to conduct this research, and finally I will explore some examples of practice centred around the two main themes of this paper: control and the alternative approach empowerment.

\section{Defining the concepts of power and control}

Teachers' power through control over their pupils in the indoor classroom is recognised by educational research (see Delamont, 1983; Pollard, 1985; Robinson, 1994). However, facilitators in outdoor education also appear to be, at times, at the epicentre of power (see Brown, 2001), particularly when assumptions about power and control, predictability and quality control are made within some outdoor learning models (see Dickson, 2005). For the purpose of this paper, power is understood as the shifting distribution of resources, which allows the participants in the educational process to attain interactional effects in an unequal manner (Hutchy, 1996). According to Hayllar (2005) power is conceptualised as the exercise of authority. Bernstein (1996) argues that power acts to create dislocations and punctuations in the social space, producing boundaries, legitimising them and reproducing them between different categories of groups (gender, class, race) and between different categories of discourse and agents. Moreover, Bernstein sees power and control as embedded in each other, but operating at different levels. Thus according to Bernstein (1996, p. 19), "power always operates on the relations between categories," establishing "legitimate relations of order", whereas control "establishes legitimate forms of communication appropriate to the different categories." In short "power constructs relations between, and control relations within given forms of interactions" (Bernstein, 1996, p. 19). In this paper, I will refer to the forms of interactions of pedagogic practice, and the category relations of pedagogic discourse in outdoor education.

The aim of this paper is to explore how control is used, at times, by teachers/facilitators as an educational tool in the outdoors and the impact that this has on the outdoor learning experience of the participants. The research on which the paper is based was carried out at a residential outdoor centre in the $\mathrm{UK}$, as part of a PhD study and involved visiting primary school groups, their teachers and the centre staff.

\section{Power and control in education and outdoor learning}

Research studies carried out by Delamont (1983) and Pollard (1985) on classroom interaction discuss issues of control and power within the indoor classroom, which are also of great importance and 
relevance in outdoor education. Pollard (1985) notes a strong desire on the part of the teachers to control their work situation and to maintain classroom autonomy. Robinson (1994) also points out that:

Controlling is in the vocabulary of most teachers. Some need it there, some want to be rid of it, but it is hard to eradicate, because the society and everything that teachers have been taught to believe goes against even becoming aware of their controlling, let alone making moves to change it. (p. 128)

Delamont (1983) recognises the position of power in which the teachers find themselves, stating that: "Teachers and pupils come to the classroom in very different bargaining positions" (p. 50). Thus, since teachers are entitled to supervise and correct the pupils' talk and behaviour, which does not happen in everyday conversation between adults, teachers have a significant amount of control over their pupils. Pollard (1985) sees teachers in a similar light as Delamont (1983) and warns against the potential dangers for the pupils of using power as an educational tool, without fully considering the consequences.

The issues of power and control are not limited to teachers in conventional, indoor education. Dickson (2005) deconstructs Priest and Gass's (1993) five generations of facilitated learning from adventure experiences, and emphasises and critiques the dominance of the instructor and the submissiveness of the participant. This dominance is present because of the placement of the facilitator in a position of power, enabling him/her to control the experience of the learner. Dickson (2005) is critical of the implication that the model of the five generations seems to make. For example, she claims that "a well-designed process (the questions) will ensure that the inputs (the people) will achieve the appropriate outputs (their own learning), but it seems that the participant can only achieve 'their own learning' through the intervention of the instructor" (p. 236).

Brown (2002) examines in more depth the outdoor facilitation process, as he focuses particularly on a group discussion between the outdoor leader and the students taking part in an outdoor programme. He points out that the model of turn-taking used in the leader-student interaction and the leader's capacity to formulate and evaluate the students' responses places the leader in a power position over the students due to their pre-assigned roles within society. Therefore, Brown (2002) calls for a re-evaluation of the literature on the role of the leader in the facilitation process. He also questions the idea put forward by Chapman (1995) that leaders play mainly a detached role, acting only as mediators.
Previously (Stan, 2009), I argued that the literature on outdoor education appears to view the facilitator either in a position of control over the participants' learning experience (Hart, 1991, 1992; Sharp, 1992; Parry, 1995; Priest \& Gass, 1997; Bendaly, 2000) or as removed from it (Chapman, 1995; Joplin, 1995; Sugarman, Doherty, Garvey, \& Gass, 2000). Despite the multitude of 'how-to' guides on facilitation (see all of the above), there appears to be a sparseness of studies exploring and analysing this process (Brown, 2005). However, Brown's (2002) in-depth analytical studies reveals that the leader is placed in the role of 'gatekeeper', with the power to create and restrict the students' opportunities for discussions, to assess their inputs and to construct and express what is deemed as 'acceptable' knowledge in the outdoor setting.

It seems that in any educational setting, where there is a lack of reciprocity and dialogue, the teacherpupil relationship becomes disempowering, with the pupils being in the disempowered position. By using control as an educational tool and by adopting practices that stifle the pupils, without creating the space for dialogue, teachers/facilitators use powerover to deprive the pupils of power-with (Kreisberg, 1992). According to Starhawk (1988) power-with refers to 'influence,' which should be distinguished from 'authority,' which she links to power-over. She argues that power-with is present in groups where each member is seen as equal to all the other members of the group. Thus the term power-with refers to the individual's power not command, "but to suggest and be listened to, to begin something and see it happen" (Starhawk, 1988, p. 10). Conversely, power-over gives the ability to the powerful individual to impose his/ her ideas, whereas power-with is 'always revocable.' Starhawk (1988) suggests that in a group where powerwith is present, group members have the opportunity to consider ideas, before accepting or rejecting them. This paper looks at practices that exhibit both powerover and power-with and the impact that such practices have on the children's outdoor learning experience. But before that, I will give an overview of the methodological approach adopted in this study.

\section{Methodological approach}

The research on which this paper is based was undertaken at a residential outdoor centre in South-East England. The participants in the research were primary school pupils visiting the centre, their teachers and the centre staff. The data were collected over two periods in 2005 and 2006, for a total of 11 weeks. During my fieldwork I observed 14 school groups, with pupils aged between 6 and 12 years. Each group was accompanied by at least two teachers from the visiting school. 
A qualitative approach was adopted for this research, taking the form of an ethnographic study. Ethnography is sensitive, holistic and complex (Davies, 1984; Griffin, 1985; Willis, 1977, Fetterman, 1989), hence ensuring a thorough and comprehensive inquiry into the outdoor education process. This research was not concerned with evaluating a particular outdoor education programme, nor did it attempt to test any existing theories, but rather it assumed an emergent design (see Maykut and Morehouse, 1994). This meant that my research evolved as my knowledge and understanding increased. This required the use of my judgement in the field and being ready for the unexpected (Hammersley \& Atkinson, 1995).

Participant observation and semi-structured interviews were used to collect a variety of data, which is essential for ethnography, as it allows for an in-depth understanding of the social phenomena studied (Walford, 2001). Thus, I recorded discussions, interviews, overheard remarks, observational notes, and some quantitative data, such as the number of pupils, their age, and gender, either by writing them down in my field notes or by tape recording. These types of data assisted me in the process of understanding and constructing the world I was studying.

The data analysis involved a search for patterns (see Spradley, 1980), which meant that I initially familiarised myself with the data, reading and re-reading the notes and the fieldwork diary, and listening to the interviews I had conducted. I then identified patterns of behaviour of the participants, repetitions in the way the activities unfolded, and comparing and contrasting the different kinds of interaction between the participants. As a result, I identified several cultural domains. According to Spradley (1980) a cultural domain is an important basic unit in every culture and domain analysis is a type of ethnographic analysis. In later steps, I undertook taxonomic analysis that involved looking into how cultural domains were organised. Taxonomies show the relationship among all the included terms in a domain and reveal subsets and the way they are related to the whole (Spradley, 1980). For instance, let us consider the cultural domain 'kinds of teachers.' Initially, I identified 22 kinds of teachers:

$\begin{array}{ll}\begin{array}{l}\text { the safety conscious } \\ \text { the nanny }\end{array} & \begin{array}{l}\text { the safety obsessed } \\ \text { the part-of-the-team } \\ \text { the detached }\end{array} \\ \begin{array}{ll}\text { the adviser } \\ \text { the indifferent } & \text { the sympathiser } \\ \text { the controller } & \text { the discussion leader } \\ \text { the helper } & \text { the authoritarian } \\ \text { the interferer } & \text { the demander } \\ \text { the watch dog } & \text { the lecturer } \\ \text { the question asker } & \text { the toughen-upper } \\ \text { the rule-breaker } & \text { the chatter } \\ \text { the team spirit builder } & \text { the peace maker }\end{array}\end{array}$

These terms are included in the domain by a single semantic relationship: $\mathrm{x}$ is a kind of $\mathrm{y}$. Moreover, these are actually approaches that a teacher may take at one particular time in the activity. It was evident however that a single teacher would not go through all these approaches, rather a teacher may go through three or four approaches, from the indifferent to the question asker, to the helper and to the interferer and then back to the indifferent.

I then carried out a componential analysis, which involved searching for the attributes of the terms in each domain. Attributes or components of meaning are contrasts among the members of a domain. Thus a componential analysis looks for the components of meaning that people have assigned to their cultural categories (Spradley, 1980). In the end, I conducted a theme analysis, which entailed "a search for the relationships among domains and for how they are linked to the cultural scene as a whole" (Spradley, 1980, pp. 87-88).

In order to present the data, I have used thick description (Geertz, 1973), which involves a description of the data in sufficient detail in order to allow the reader to visualise the situation being described, which may contribute to the credibility of the research. According to Delamont (1992) thick description "aims to make the familiar strange and the exotic familiar, via the analytic categories or themes" (p. 150).

\section{Ethical considerations and practical issues}

When conducting an ethnographic study there are serious ethical issues that the researcher has to consider before entering the field and while being there. The goal of ethnography is to produce knowledge, however this has to be done without causing any harm to the participants involved in the research, without deceiving (see Hammersley \& Atkinson, 1995) or infringing on the privacy of the participants.

I decided to conduct an overt study, and therefore chose not to deceive the participants in the research. Consequently, when I began my fieldwork I made sure that all the staff, the pupils and visiting teachers were aware of the fact that I was conducting research. The centre took the responsibility of informing the schools of my presence and that I was conducting research there. This was because they were in constant contact with the schools and had developed a relationship of trust over the years. This proved of tremendous help to me, as it meant that the initial stage of getting consent from the schools was done through the main gatekeepers, which alleviated any issues of trust I may have encountered if I had asked for consent myself from the individual schools. Trust in the researcher 
is not something to be taken for granted as schools may often be reluctant to be involved in any kind of research (Walford, 2001).

The extent to which I explained what my research entailed varied, depending on the person soliciting the information. I did not see it necessary to go into much detail, unless the person would manifest further interest (Fetterman, 1989), so I only presented a general idea of the research. Therefore, when pupils would ask me what I was doing there, I would simply tell them that I was writing a book about children and that I needed to record what they were doing and what they were saying. They seemed to be very pleased about it and many of them asked me if they could read it. My answer would be: "Of course, but you have to wait two more years until I finish it." Their response usually was: "Oh no, that long!"

According to Maykut and Morehouse (1994) the people studied are participants in the research, and therefore they should be seen as essential collaborators who, together with the researcher, can shape and determine what is to be understood about them and their situation. That is why I have chosen the word 'participant' to refer to the people in my study, instead of 'subject,' which implies superiority of the researcher (Van Maanen, 1988; Vidich and Lyman, 2000).

With undertaking overt research the issue of obtaining informed consent from the participants becomes central. In my case, it was an even bigger matter because I was around young children. Thus I had to undergo a check with the Criminal Records Bureau (CRB). Before beginning any observations, I also asked the permission of the pupils to accompany them on their activity and if they minded if I took notes of what they were doing and saying. The response was always positive, and they did not seem to be too bothered by my presence, and on many occasions, I was asked for advice or encouraged to join in the activity. I also made sure that I had the verbal consent of the facilitators working at the centre, asking for their permission before I accompanied them on the activity.

The ethnographer himself/herself is the primary source of data (Woods, 1994), consequently subjectivity is an inescapable reality of the research act (Walford, 2001). Therefore, I attempted to bring to light the assumptions and values implicit in the research and the implications behind acknowledging that I was part of, rather than outside, the research act (Walford, 2001). Since I, the researcher, was inevitably part of the world I was studying, instead of trying to deny this fact and remove myself from it, I embraced it, by being aware of the effects that my presence had on the people within that world and their actions. How people react to the presence of the researcher is as important data as how they respond to other situations and should therefore be taken into consideration when analysing the data. Instead of trying to completely eliminate the effects of the researcher, it is best to try and understand them (Hammersley and Atkinson, 1995).

In order to ensure the anonymity of the participants I only used pseudonyms and I chose not to use the real name of the outdoor centre (Christians, 2005), so I simply refer to it as 'the centre.' In the extracts from the field notes, I use Pg to refer to a female pupil and $\mathrm{Pb}$ to refer to a male pupil. $\mathrm{Pb} 1, \mathrm{~Pb} 2$ and $\mathrm{Pb} 3$ are used to show the different pupils involved in the conversation. Pgs, Pbs and Ps show that pupils are speaking in unison. Tm is used to designate a male teacher, and Tf a female teacher. Since I was able to build a stronger rapport with the staff at the centre, due to the extended time spent there, I got to know them quite well, so I decided to use pseudonyms for the facilitators. I have also done so for some of the pupils, if they played an important part in the interaction. I have used square brackets to mark any interpretations on my part, which I included in the field notes, and used [...] to show that parts of the conversations had been left out.

\section{Order and instructions as controlling practices}

What follows is an exploration the processes occurring in the outdoor setting where the research was conducted, by examining how some of the teachers and the facilitators (centre staff) approached the delivery of the programmes to the pupils. I will show the ways in which the related concepts of empowerment and control that have emerged as the main themes from the research emphasised the importance in practice of the impact that the participant approaches had on the learning experience. These concepts are shown to be an intrinsic part of the learning process at the centre.

On the one hand, I will call attention to contexts that appear to disempower the participants, which may interfere with the learning process. On the other hand, I will highlight the forms of discourse and practices that can be empowering and that can create a favourable environment for learning to occur. First, I will focus on two scenarios that show how order and instructions are used by the teachers/facilitators as a form of control over the pupils.

The first scenario takes place during the blind string trail, an activity that was considered a team building activity by the centre. The blind string trail requires the participants to be blindfolded by wearing goggles. The participants form a human chain and have to guide each other through an obstacle course, relying only on their senses of hearing and touch and on their communication skills. Many pupils would complain about the goggles hurting them during this 
activity. Some teachers would allow them to take them off from time to time and have a break. However the teachers adopting the controlling approach would not allow the pupils touching the goggles. Trying to lift the goggles off was seen as an attempt to cheat, as it can be seen in the example below. It was a really hot day, and the pupils appeared to be struggling with the goggles, complaining that they were too tight. Any attempt on the part of the pupils to re-adjust them was highly reprimanded:

\section{They lean on the string and they all fall off on their bums. The teachers help them up.}

Tf: Kerry, what are you doing lifting those goggles? I caught you right in the act! [angrily, with a reprimanding voice] (Field notes I, pp. 118-119, 20.06.2005)

If a pupil got hurt or was struggling with the activity, there was little or no verbal comforting, only physical assistance from some teachers who appeared to be more concerned with keeping the order. This is illustrated in the extract below with the same school group as above:

\section{$\mathrm{Pb}$ : I don't want to do it! \\ Tf: You big baby! \\ $\mathrm{Pb}$ : I don't want to do it! \\ Tf: Everyone's doing it, otherwise I'm sending you back home. (Field notes I, p. 133, 20.06.2005)}

The boy had no choice in the matter, because the order had to be maintained: 'everyone's doing it.' The teacher did not give him the opportunity to express why he did not want to do it, or even attempt to negotiate the situation. Teachers using order and instructions tended to be less comforting when interacting with pupils, as it can be seen in the following example:

\section{One boy had a fly on his arm, he was very distressed.}

Tf: It wasn't a wasp, it doesn't sting.

$\mathrm{Pb}$ : It stings! (holding his hand and squeezing his eyes, almost crying)

Tf: Come on, you have to toughen up! (Field notes I, p. 109, 20.06.2005)

Soon after this incident, the boy lost interest in the activity and started chatting with another female teacher who tried to comfort him. There was no attempt that I could see on the part of either teacher to try to get the pupil more involved in the activity, to motivate him. It appeared that their main concern was to contain the situation, so that the others could get on with the activity undisturbed.
As it was shown above, some teachers exercised control as an education tool, using order and instructions as controlling practices. These teachers had a propensity not to tolerate any breaking of the rules of the activity, and they would not be flexible.

At times, teachers/facilitators would become frustrated when their use of order and instructions did not yield the desired outcomes. This happened with George, one of the facilitators at the centre, who used verbal reprimands when the pupils were struggling with the task:

George: You guys are useless, useless, you don't talk to each other, you don't listen. I say lift and you pull. You are not working as a team!

(They try again. George guides them.)

George: Girls, you let down, boys, you pull a little! Girls pull yours in! Boys, let yours out!

(They fail again.) (Field notes II, pp. 63-64, 06.07.2005)

The activity was toxic waste. The activity is carried out in an enclosed area. There is a big circle made out of string tied to small pins in the ground with a black bin in the middle, with six black plastic tubes around it. The participants are given four pieces of string and thick elastic type bands and are instructed to put the plastic tubes into the bucket without entering the circle. This was also considered a team building activity by the centre.

This was another hot day, and the activity was conducted in an area with no shade. George had taken control over the activity from the very beginning, creating only limited opportunities for the pupils to take initiative and to work together on their own terms. He started the activity by telling the pupils that they should work as a team, but he did not discuss with them what a team is. In the beginning, he did allow the pupils to discuss a plan for tackling the task, but this was closely supervised.

George appeared to be more focused on the task itself, rather than the process. By giving the pupils specific instructions, he alienated them from the activity. What followed was that the pupils started to argue with each other. George attempted to solve the conflict by not allowing the pupils to communicate verbally and by appointing a leader:

Pg1: You need to release yours!

Pb1: No, I don't. (Shouting.)

Pgs: Yes, you do! (Shouting.)

Pb2: Yeah, you do!

He releases it. [...] 
They are still fighting. [They don't seem to be able to work together.] George is shaking his head. He shouts at them.

George: OK, everyone shuuuut up! Shut up! From now on you are not allowed to talk.

He chooses a girl to direct them. They all get quiet. They listen to the girl. The boy that wouldn't release the string mumbles. [He doesn't seem to agree with her.] (Field notes II, pp. 65-66, 06.07.2005)

The appointed leadership was only temporary, as George stepped in again with instructions:

[George takes over again.]

George: Ok, girls, get round the bin, round the bin. Well done! (Field notes II, pp. 66, 06.07.2005)

In this example, praise may be seen as a form of control (Bernstein, 1996; Pollard, 1985), and not as an empowering practice. When the activity ends, the facilitator appears to have disempowered the pupils, by not allowing them to put across their own thoughts about the experience. Instead he criticised them and told them what he believed they should have done, dismissing their opinions:

George: Ok, guys, do you think you worked well Ps: Yeah! as a team?

George: Really? [He seems surprised]

Ps: Eeerm? (They look at each other) [They seem confused].

George: Did you work well as a team in the beginning?

Ps: No.

George: No. You were shouting at each other, you need to listen to each other and communicate better, alright? (Field notes II, pp. $67,06.07 .2005)$

It seems a 'lose, lose' situation, since neither the facilitator, nor the pupils in this example appeared to have enjoyed the activity and they all seemed frustrated and disappointed. Unfortunately, this happened quite often, which supports Dickson (2005) argument that 'the well-designed process' does not seem to have the expected 'outputs' (p. 236).

According to Pollard (1985) order and instructions are very important for teachers, and are used to maintain the teacher's authority and independence; stress is also avoided by keeping order within the classroom. Many aspects of teachers' disciplinary and instructional goals represent a means of achieving ends, which suit the teachers. This was certainly apparent at times within the outdoor classroom, where teachers / facilitators adopting the controlling approaches would use order and instructions to take control over the activity, as it has been shown above. They tended not to allow pupils to make any decisions. Moreover, they would deny the pupils their independence. They also had a tendency to make use of verbal reprimands and punishment on many occasions.

It appears that through the use of order and instructions some teachers/facilitators simply wanted to achieve their own disciplinary goals. This made them unable to step back from the activity and give the pupils the opportunity to work independently on the task. This led, on occasion, to the learning outcome of the activity not being achieved, which could have been caused by the controlling approach adopted by the teachers / facilitators.

\section{The empowering approach - an alternative to control}

Some teachers and facilitators supported the pupils during the activity, by offering encouragement and advice when they appeared to need it. They comforted them when they were frustrated or when they got hurt. They also allowed them to work independently, and make their own decisions on how to solve the task. For such teachers/facilitators, trying to get everybody involved appeared to be more important than accomplishing the task. This kind of pupil-teacher interaction is what Robinson (1994) identifies as an empowering practice, which gives the pupils a sense of ownership in the outdoor classroom, by allowing and encouraging them to have a choice, act independently and make their own decisions in the outdoor classroom. Thus, the children feel that the classroom is theirs too, and does not only belong to the teacher/facilitator. Glasser (1990) argues that providing choice in a classroom contributes to satisfying the pupils' need for freedom and power and this adds, according to Robinson (1994), to the pupils' sense that they can meet their needs on their terms, which is, as Robinson suggests, a feeling that human beings have to satisfy.

As an example of the sense of ownership through choice and independence within the outdoor classroom, I will refer to an extract from my observations where a facilitator seemed to be sensitive to the pupils' needs and was able to evaluate the level of intervention during the activity. She engaged the pupils in discussions, which seemed to help them to reflect on how they worked during the activity. These discussions enabled the pupils to be critical about themselves, without having to be told what they did wrong. This it is illustrated in the dialogue below:

Susan: Ok guys, how did you think you did as a team?

Ps: Good!

Susan: From 1 to 5 .

Ps: 4. 
Susan: Ok, you said 4. That means that you feel you could improve something. What is that?

Ps: Communication.

Susan: What does that entail?

Pbs: Listening, talking more.

Pgs: More planning. (Field notes II, pp. 218-219, 14.07.2005)

During this particular activity, which was the low ropes course, Susan intervened only a few times. Although Susan did take a step back, she seemed to be very much interested in what was going on and my observations suggest that she helped the pupils only when they appeared to be struggling. Therefore she managed to achieve a balance between stepping back and getting involved.

According to Boyes (2005), teachers working in the outdoors should offer and facilitate meaningful learning experiences without putting at risk the participants both physically and psychologically. This suggests that they have to try to find a balance between providing enough cognitive and physical challenge to stimulate the learners and ensure their safety. The facilitator in the example above appeared to have achieved not only the kind of balance that Boyes (2005) refers to, but also made it possible for the pupils to learn how to work as a team in their own terms. She accomplished this, I believe, because she allowed them the space they needed, and gave them independence and responsibility. A sense of ownership of the outdoor classroom was thus achieved.

Moreover, through the open dialogue that the facilitator had with the pupils and by engaging them in reflective thinking, the pupils learned together how to work as a team, and be critical about themselves. This can be described as an empowering approach. The degree to which an approach can be considered empowering depends on the practices and the forms of discourse used. Empowering practices recognise that education is not only limited to intellectual and cognitive pursuits, and comprises the whole prism of human experience in the classroom: the emotional, the social, the physical, the moral, the creative (Robinson, 1994, p. 156).

Such practices lead to the personal growth of those involved in the interaction, as Robinson (1994) points out:

Empowering practices are meaningful and need-fulfilling for other teachers in the school, for parents and administrators, as well. All participants allow themselves and feel allowed by others to be more of who they are, and to keep growing and eventually becoming more fully human. (p. 156)
By analysing different interactions and approaches of the participants, I have shown how open dialogue between the participants creates a safe environment where learning is a social experience, which is empowering all the participants. I have illustrated that empowering practices create an environment where learning becomes a beneficial social experience, as pupils are able to share their thoughts, opinions and feelings with the teachers/facilitators and their peers, they are given the opportunity to make their own decisions and are encouraged to reflect on what they have done and learned.

\section{Conclusions}

Although control may seem at times an attractive educational tool (see Delamont, 1983; Pollard, 1985), this paper has shown that in some cases using controlling practices can lead to failure to achieve the desired learning outcomes. The findings suggested that when control was exercised over the pupils taking part in outdoor activities, this impacted on the pupils' learning experience in a negative way, since the desired learning outcomes did not appear to be achieved. Thus children taking part in team-building activities were, at times, unable to learn how to work as a team, as there was no dialogue encouraged and the pupils were not allowed to work independently. However, when facilitators created the space for communication to be shared and would take a step back from the activity, the pupils learned what it meant to work as a team, and were critical of themselves.

Pollard (1985) notes that 'flexibility' and 'adaptability' are the only viable strategies in the long run, and that the establishment of a 'good relationship' between teacher and pupil is essential for the successful work with young children. Yardley (1976) stresses the importance of 'good relationships' when he points out that: "the quality of relationships within the school is at the root of the discipline which pertains there..." (p. 67).

The beneficial effects of open dialogue in education have been illustrated by Skidmore (2000) who compared two different interaction styles. One of the teachers controlled the learning in an authoritative style. The other promoted more open-ended thinking and response to the text, by asking questions that invited the children to articulate their views, handing control to the children. The former casts the teacher as the possessor of knowledge that must be conveyed to the children. The latter is the internally persuasive discourse that celebrates "the primacy of dialogue, the impossibility of any word ever being final" (Skidmore, 2000, p. 292). The findings of the study discussed in this paper have highlighted that dialogue is also essential in the outdoor educational setting, since it encourages the pupils to express their feelings, and thoughts freely. This can be described as positive 
interaction, which, according to Lindh (1983), can improve pupil achievement, increase motivation and self-esteem, and contribute to the development of personality. Open dialogue is a process that actively involves the participants in liberating learning, it is not simply a method by which content is taught, it is the whole network of interactions and relationships, which comprise learning (see Robinson, 1994).

This study adopted an ethnographic approach in an attempt to give a fine-grained description of the facilitation process in the outdoors, in order to allow for some insight into how the use of control can have a negative impact on the outdoor learning experience of the participants. While no claims for generalisability can be made, due to the 'rich' and 'thick' descriptions of the phenomena (Geertz, 1973) discussed in this paper, 'naturalistic generalisations' (Stake, 2000) may be arrived at by the reader. Furthermore, the reference to the theory and empirical studies, contributes to the understanding of the processes discovered and have not been used to evaluate or generalise. Nor is the intention of this paper to provide a 'best-practice' guide, or any kind of prescriptive principles to be followed. It simply calls for a critical analysis of the outdoor facilitation process, and it encourages all practitioners in the area to review both their role and approach to teaching in the outdoors (see also Brown, 2002).

By making the process transparent, and illustrating the significance of the impact that the facilitator has on the participants' outdoor learning experience, it is hoped that practice in the outdoors may be influenced more and more by the theory developed from empirical studies such as Brown's (2002) and the one described in this paper. There is a need to bridge the gap between research, theory and practice in outdoor education (Richards et al., 2005). Such gaps exist, because much of the research carried out in outdoor education has mainly looked at the outcomes of outdoor education, rather than the process itself (see Beames, 2004). Rickinson et al. (2004, p. 56) point out that research needs to be aimed more at the process and the social interactions between the participants, as these represent some of the 'blank spots' within research in outdoor education (see also Beames, 2004; Seaman, 2007). This paper has attempted to fill in some of those spots, but due to the complexity of this outdoor educational process, more studies are needed, particularly studies taking a qualitative, perhaps ethnographic approach (see Richards et al., 2005; Brown, 2002).

\section{References}

Beames, S. (2004). Critical elements of an expedition experience. Journal of Adventure Education and Outdoor Learning, 4(2),145-157.

Bendaly, L. (2000). The facilitation skills training kit. New York: McGraw-Hill.

Bernstein, B. (1996). Pedagogy, symbolic control and identity: theory, research, critique. London: Taylor \& Francis.

Boyes, M.A. (2005). Making teaching decisions in the outdoors: Optimising learning and safety. In T.J Dickson, T. Gray and B. Hayllar (Eds), Outdoor and experiential learning: Views from the top (pp. 220-229). Dunedin: Otago University Print.

Brown, M. (2001). What does a close reading of interaction tell us about how we conduct facilitation sessions, The 12th National Outdoor Education Conference: Education Outdoors - our Sense of Place Proceedings, La Trobe University Bendigo, Victoria 15-18, Jan 2001, pp. 109-126.

Brown, M. (2002). The facilitator as gatekeeper: a critical analysis of social order in facilitation sessions. Journal of Adventure Education and Outdoor Learning, 2(2), 101-112.

Brown, M. (2005). Rethinking the role of the facilitator: What a close examination of talk reveals. In T.J Dickson, T. Gray and B. Hayllar (Eds), Outdoor and experiential learning: Views from the top (pp. 240-249). Dunedin: Otago University Print.

Chapman, S. (1995). What is the question? In K. Warren, M. Sakofs and J. Hunt, Jr. (Eds), The theory of experiential education (3rd ed., pp. 236-239). Dubuque, IA: Kendall/ Hunt.

Christians, C.G. (2005). Ethics and politics in qualitative research. In N.K. Denzin and Y.S. Lincoln (Eds), The Sage handbook of qualitative research (3rd ed., pp. 139-164). Thousand Oaks, CA: Sage.

Davies, B. (1982). Life in classroom and playground. London: Routledge and Kegan Paul.

Delamont, S. (1983). Interaction in the classroom: Contemporary sociology of the school (2nd ed.) London: Methuen.

Delamont, S. (1992). Fieldwork in educational settings: Methods, pitfalls and perspectives. London: The Falmer Press.

Dey, I. (1993). Qualitative data analysis: A user-friendly guide for social scientists. London: Routledge.

Dickson, T. (2005). Deconstructing 'the five generations of facilitated learning from adventure experiences.' In T.J. Dickson, T. Gray and B. Hayllar (Eds), Outdoor and experiential learning: Views from the top (pp. 230-239). Dunedin: Otago University Print.

Fetterman, D.M. (1989). Ethnography - step by step. London: Sage. 
Geertz, C. (1973). Thick description: Towards an interpretive theory of culture. In C. Geertz (Ed.), The interpretation of cultures: selective essays. New York: Basic Books.

Glasser, W. (1990). Quality school. New York: Harper and Row.

Griffin, C. (1985). Typical girls? Young women from school to the job market. London: Routledge and Kegan Paul.

Hammersley, M. \& Atkinson, P. (1995). Ethnography: Principles in practice. London: Routledge.

Hart, L. B. (1991). Faultless facilitation: An instructor's manual for facilitation training. Amherst, MA: Human Resources Development Press.

Hart, L. B. (1992). Faultless facilitation: A resource guide for group and team leaders. Amherst, MA: Human Resources Development Press.

Hayllar, B. (2005). Leadership and facilitation. In T.J. Dickson, T. Gray and B. Hayllar (Eds), Outdoor and experiential learning - views from the top (pp. 179-183) Dunedin, New Zealand: Otago University Print.

Humberstone, B. (1997). Challenging dominant ideologies in the research process. In G. Clarke \& B. Humberstone (Eds), Researching women and sport (pp.199-213). London: Macmillan Press.

Hutchby, I. (1996). Power in discourse: The case of arguments on a British talk radio show. Discourse and Society, 7(4), 481-497.

Joplin, L. (1995). On defining experiential education. In K. Warren, M. Sakofs and J. Hunt, Jr. (Eds), The theory of experiential education (3rd ed, pp. 15-22). Dubuque, IA: Kendall/Hunt.

Kreisberg, S. (1992). Transforming power: Domination, empowerment and education. New York: State University of New York.

Lindh, R. (1983). Learning through imaging. A guide to learning based on suggestion. Porvoo: Werner Söderström Osakeyhtiö.

Parry, L. (1995). Effective facilitators - a key element in successful continuous improvement processes. Training for Quality 3(4), 9-14.

Pollard, A. (1985). The social world of the primary school. London: Holt, Rinehart and Winston.

Priest, S. \& Gass, M.A. (1993). Five generations of facilitated learning from adventure experiences. Journal of Adventure Education and Outdoor Leadership, 10(3), 23-25.
Priest, S. \& Gass, M. (1997). Effective leadership in adventure programming. Adelaide: Human Kinetics.

Robinson, H.A. (1994). The ethnography of empowerment: The transformative power of classroom interaction. Washington D.C.: The Falmer Press.

Seaman, J. (2007). Taking things into account: Learning as kinaesthetically-mediated collaboration. Journal of Adventure Education and Outdoor Learning, 7(1), 3-20.

Sharp, P. A. (1992). The 'never-evers' of workshop facilitation. Journal of Staff Development, 13(2), 38-40.

Skidmore, D. (2000). From pedagogical dialogue to dialogic pedagogy. Language and Education, 14(4), 283-96.

Stan, I. (2009). Recontextualizing the role of the facilitator in group interaction in the outdoor classroom. Journal of Adventure Education and Outdoor Learning, 9(1), 23-43.

Starhawk, (1988). Dreaming the dark: Magic, sex and politics. Boston: Beacon Press.

Spradley, J.P. (1980). Participant observation. New York: Holt, Rinehart and Winston.

Sugarman, D.A., Doherty, K.L., Garvey, D.E. \& Gass, M.A. (2000). Reflective learning: Theory and practice. Dubuque, IA: Kendall/Hunt.

Walford, G. (2001). Doing qualitative educational research: A personal guide to the research process. London: Continuum.

Walford, G. (Ed.) (2002). Doing a doctorate in educational ethnography, Vol. 7. Oxford: Elsevier.

Willis, P. (1977). Learning to labour: How working class kids get working class jobs. Farnborough: Saxon House.

Yardley, A. (1976). The organisation of the infant school. London: Evans.

\section{About the author}

Ina Stan was awarded her PhD by Brunel University for research undertaken at Buckinghamshire New University in 2008. She worked as a post-doctoral research assistant and a part-time lecturer within the School of Sport, Leisure and Travel at the same university. She has been working on a pilot study entitled the Well-being and Outdoor Pedagogies. She is also undergoing research on Pregnancy, Leisure and the Well-being of Women. Her research interests are in ethnographic studies, group interaction, and education, particularly outdoor learning with primary school children. Email: Ina.Stan@bucks.ac.uk 